\title{
Effects of Pyrethroid Pesticide Cypermethrin on the Gonad and Hemato-biochemical Parameters of Female Gangetic Mystus (Mystus cavasius)
}

\author{
Md. Helal Uddin ${ }^{1}$ (D) Md. Haider Ali ${ }^{1}, K^{2}$ Mar Ahmed Sumon ${ }^{1}$, Md. Shahjahan $^{1}$ (D), \\ Harunur Rashid ${ }^{1, *}$ if
}

${ }^{1}$ Bangladesh Agricultural University, Department of Fisheries Management, Mymensingh-2202, Bangladesh.

\begin{abstract}
How to cite
Uddin, M.H., Ali, M.H., Sumon, K.A., Shahjahan, M., Rashid, H. (2022). Effects of Pyrethroid Pesticide Cypermethrin on the Gonad and Hematobiochemical Parameters of Female Gangetic Mystus (Mystus cavasius). Aquaculture Studies, 22(3), AQUAST819. http://doi.org/10.4194/AQUAST819
\end{abstract}

\section{Article History}

Received 18 November 2021

Accepted 27 January 2022

First Online 31 January 2022

\section{Corresponding Author}

Tel.: +8801924429971

E-mail: rashid@bau.edu.bd

\section{Keywords}

Pesticide

Gonads

Histopathology

Hematology

Gangetic mystus

\begin{abstract}
A 90-day experiment was conducted to study the effect of sub-lethal concentration of cypermethrin exposure on mortality, Gonadosomatic index (GSI), ovarian cell development and hemato-biochemical parameters of Gangetic mystus (Mystus cavasius). According to previous findings of LC50 value $(30 \mu \mathrm{g} / \mathrm{L})$ of cypermethrin the experiment was carried out using four sub-lethal concentrations as treatment $(0.0,4.0$, 8.0 , and $16.0 \mu \mathrm{g} / \mathrm{L}$ ). The whole water was exchanged in every $4^{\text {th }}$ day and pesticide was mixed accordingly. For collection of gonad and blood, fish were sampled at 30,60 and 90 days after starting of pesticide exposure. There were no significant changes on GSI. Several histopathological changes were observed in ovary. Wrinkle oocyte, cytoplasmic clumping, atretic follicle, degenerated granulose layer, degenerated oocyte wall, increased inter follicular space, adhesion, cyst, necrosis were found in the ovary of $M$. cavasius with increasing cypermethrin concentration and exposure time. Blood glucose level and WBCs were significantly increased whereas blood hemoglobin and RBCs were significantly decreased in exposure groups compared to control groups over the three sampling days. The current findings revealed that cypermethrin had negative impact on the hemato-biochemical parameters and female gonad of $M$. cavasius. So the use of cypermethrin in agriculture should be done with a great caution.
\end{abstract}

\section{Introduction}

Bangladesh is a densely populated country with high population growth rate. To meet the food demand for the increasing population, the government of Bangladesh has promoted the use of pesticides for producing more agricultural crops (Dasgupta et al., 2007). There was very minimum use of pesticides in Bangladesh before 1960s but abruptly increased about 7 times in amount from 1992 to 2010 (Ali et al., 2018). High Yielding Varieties (HYVs) are very much susceptible to pest for that reason the uses of pesticides are in increasing trends that also makes our environment polluted (Sumon et al., 2016). Pesticides eventually find their way into aquatic environments in many ways like spray drift, run off and leaching (Van den Brink, 2013; Shahjahan et al., 2017). This insecticide into the aquatic environment may have potential toxic effects on nontarget aquatic organisms like invertebrates (Rubach et al., 2011; 2012), and vertebrates (Manjunatha and Philip, 2016; Sumon et al., 2017). Considering the importance of fish as food as well as having long life span and ability to response against environmental xenobiotics treated as a good bio-indicator among vertebrates (Gupta et al., 2009; Narra et al., 2011; Correia et al., 2017). There are four pesticide groups among them cypermethrin belongs to pyrethroid having a good commercial agricultural applications as it 
considered a fast acting neurotoxin in insects. According to the National Pesticides Telecommunications Network (NPTN) cypermethrin is very much toxic to fish, bees and other aquatic insects. It is easily degraded on soil and plant and can be effective on water up to 30 days. Decomposition of this pesticide will stimulate when exposure to sun light, water and oxygen.

Pesticides are found in different types of water bodies from lower to higher concentrations and resulted to be toxic for aquatic organisms especially for fish (Banaee et al., 2008). The impacts of this type of pesticide are the occurrences of muscle convulsion along with loss of balance of $\mathrm{Na}$ and $\mathrm{K}$ in neuron and finally stopped the activities of central nervous system (Sachsen and Sultana, 1999). Fish may be directly affected by pesticides in many ways like changes in normal behavior e.g. feeding or swimming (Satyavardhan, 2013; Ullah et al., 2014; Rani and Kumaraguru, 2014), alteration of physiological functions such as changes in blood parameters (Blood glucose, $\mathrm{Hb}$, WBCs, RBCs etc) as well as histo- architectural changes in some important internal organs like liver, kidney, intestine etc. (Saeedi et al., 2012; Salam et al., 2015; Sharmin et al., 2015). Cypermethrin may also affect the reproductive system of fish which is an important consideration for evaluating the impacts of pesticide chemicals (De Silva and Samayawardhena, 2005).

The effects of pesticide pollution on non-target organisms (e.g. fish) can be measured by detecting changes in organisms at the physiological, biochemical or molecular levels, which can provide 'early warning' tools in monitoring environment quality (Crane and Maltby, 1991; Miren et al., 2000). These sensitive early warning biomarkers can measure interaction between environmental xenobiotics and biological effects. Hematological parameters are commonly used as a significant index for measuring the health condition of the fish (Ruane et al., 2000; Okomoda et al., 2013). The physical and chemical changes of water may be expressed in the blood components of fish (Wilson and Taylor, 1993). Blood parameters can provide a lot of information about physiological response of fish to environmental changes that affect homeostasis (Lohner et al., 2001; Cazenave et al., 2005; Elahee and Bhagwant, 2007; Sharmin et al., 2015; Salam et al., 2015). The analysis of haematological and biochemical parameters in fish can contribute to the assessment of the animal's health and also the habitat conditions (Thrall, 2004).

There are about 260 freshwater fish species in Bangladesh among them 143 is considered as small indigenous fish species (SIS) having maximum size in length less than $25 \mathrm{~cm}$. Gangetic mystus is a popular SIS in Bangladesh due to its taste and nutritional value and also found in Nepal, India, Pakistan, Sri Lanka and West Africa (Yadav, 1997). Rivers, lakes, canals, floodplains, swamps, ponds and ditches are considered as natural habitat for feeding and breeding of this fish species (Talwar and Jhingran, 1991). Gangetic mystus is locally known as gulsa. There are a number of researches conducted all over the world assessing the toxicity of cypermethrin on the reproduction and haematological parameters of different fishes but not yet on Gangetic mystus. Therefore, the present study aimed at assessing the toxicity of cypermethrin on the reproductive organs along with hemato-biochemical parameters of $M$. cavasius.

\section{Materials and Methods}

\section{Experimental Fishes}

Healthy and living female Gangetic mystus was procured from a local reputed fish farm and disinfected in $0.1 \%$ solution of potassium permanganate for 5 minutes to avoid dermal infection. They were reared in an indoor cemented rectangular cistern with continuous aeration for three months at wet laboratory, Bangladesh Agricultural University. The experiment was conducted under natural light and ambient temperature condition. Due to nocturnal behavior fish were fed at evening at a rate of $4 \% / \mathrm{kg}$ body weight. The experiment was approved by the Animal Care and Use Committee of Bangladesh Agricultural University, Mymensingh, Bangladesh.

\section{Pesticide}

Technical grade synthetic pyrethroid (cypermethrin) 10\% EC active ingredient manufactured by Hayleys PLC, Sri Lanka was purchased from a local registered pesticide seller (Mymensingh, Bangladesh).

\section{Experimental Design}

Total 240 mature female Mystus cavasius (length=13.2 $\pm 0.72 \mathrm{~cm}$; weight=15.71 $\pm 1.09 \mathrm{~g}$ ) were selected for the experiment. Previously prepared 12 PVC tanks having $100 \mathrm{~L}$ de- chlorinated tapwater with aeration facilities were used to ensure sufficient oxygen supply during the experimental period of 90 days. Twenty female fish were stocked in each of the PVC tank and acclimatized at laboratory condition for a period of 21 days prior to pesticide exposure. Fish were exposed to four different concentrations of cypermethrin $(0,4.0$, 8.0 and $16.0 \mu \mathrm{g} / \mathrm{L}$; the $96-\mathrm{h}$ LC50 in this study was 30 $\mu \mathrm{g} / \mathrm{L}$ ) for 30, 60 and 90 days. The control and treatments were set up in three replicates. Water (about 80\%) in the experimental units was changed every three days and fresh cypermethrin concentrations were used.

\section{Gonads Collection and GSI Estimation}

To prevent suffering during gonad collection test fish were anesthetized using clove oil $(5 \mathrm{mg} / \mathrm{l})$ on days30, 60 and 90 after the first cypermethrin exposure. Three fish were sacrificed from each replication at each sampling day. Immediately after collection of ovary electric balance was used to weight and rinsed with 
physiological solution ( $0.9 \%$ sodium chloride) and transferred to $10 \%$ buffered formalin solution at ambient temperature for appropriate fixation. The GSI was measured using following formula: GSI = [(gonad weight/body weight) $\times 100$ ]

\section{Histopathology of Gonads}

In order to histological observation, the collected ovarian tissues were washed with running tap water and passed through a graded series of alcohol for dehydration then in benzene for clearing and embedded with using paraffin. The paraffin blocks were sectioned with a thickness of $5 \mu \mathrm{m}$ using microtome and stained with hematoxylin and counterstained with eosin. Finally, the histopathological alterations were photographed using digital photomicroscope (Olympus CX 41).

\section{Blood Sampling}

For collecting blood, fish were anesthetized with clove oil $(5 \mathrm{mg} / \mathrm{l})$ and blood was collected by cutting the caudal peduncle and pushed into a sterilized centrifuge tube containing anticoagulant (20mM EDTA). The blood collection process for each fish took less than one minute to minimize stress impacts on normal blood values.

\section{Measurement of Hemato-biochemical Parameters}

Blood glucose level $(\mathrm{mg} / \mathrm{dl})$ was measured using glucose strips in adigital EasyMate ${ }^{\circledR} \mathrm{GHb}$, blood glucose/hemoglobin dual-function monitoring system (Model: ET- 232, Bioptik Technology Inc. Taiwan 35057). SAHLI's hemometer (Model-3243000, MARIENFELD, Germany) was used to calculate the $\mathrm{Hb}(\%)$ following the routine procedure. Total count of RBCs and WBCs were done by established Neubaur haemocytometer counting method.

\section{Semi-quantitative Analysis}

Histological evaluation like mean assessment value (MAV), degree of tissue changes (DTC) and observed frequency of the pathological lesions were evaluated after observing six sections per fish tissue by light microscope (Olympus CX 41). Semi-quantitative observations on histopathological alterations were done according to Schwaiger et al. (1997) with some modifications. A numerical value was given for each alteration according to their frequency of occurrences

\section{Statistical Analysis}

Values were presented as, means \pm standard deviation (SD). We used one-way analysis of variance (One-way ANOVA) followed by Tukey's post hoc test. Statistical significance was set at $p<0.05$. Data were analyzed using SPSS (version 14.0).

\section{Results}

\section{Effects of Cypermethrin on Mortality}

The calculated 96-h LC10, LC50 and LC90 (with 95\% confidence limits) of cypermethrin for Gangetic mystus were $13.6,25.5$ and $46.6 \mu \mathrm{g} / \mathrm{L}$ respectively. During the static bioassay, mortality was not observed in the control groups. The short term 24h LC50 for Gangetic mystus was around $30 \mu \mathrm{g} / \mathrm{L}$ with the LC10 and LC90 being 1.5 times lower and higher, respectively (Table 1). Similarly, at $48 \mathrm{~h}$ the LC50 value $(29.5 \mu \mathrm{g} / \mathrm{L})$ is two times higher and lower than LC10 and LC90 values sequentially. Whereas the LC90 at $72 \mathrm{~h}$ was maximum around $60 \mu \mathrm{g} / \mathrm{L}$ with near about two times and three times higher than LC50 and LC10 values individually.

\section{Effects of Cypermethrin on GSI}

We measured female GSI at day-30, -60 and -90 after exposure to four different pesticide concentrations. At the day- 30 and -60 , the values of female GSI were decreased with increasing pesticide concentration compared to control group. While in the day- 90 female GSI were more or less similar among all pesticide treated groups along with control group (Figure 1).

Table 1. Number of dead individuals of Gangetic mystus exposed to different concentrations of cypermethrin during the experimental period.

\begin{tabular}{lcccc}
\hline Cypermethrin concentrations $(\mu \mathrm{g} / \mathrm{L})$ & \multicolumn{4}{c}{ Exposure time $(\mathrm{h})$} \\
\cline { 2 - 5 } & $24 \mathrm{~h}$ & $48 \mathrm{~h}$ & $72 \mathrm{~h}$ & $96 \mathrm{~h}$ \\
\hline 0 & 0 & 0 & 0 & 0 \\
5 & 0 & 0 & 0 & 0 \\
10 & 0 & 0 & 0 & 0 \\
15 & 0 & $10 \pm 0$ & $20 \pm 0$ & $20 \pm 0$ \\
20 & $15 \pm 7$ & $25 \pm 7$ & $30 \pm 14$ & $30 \pm 14$ \\
25 & $35 \pm 7$ & $35 \pm 7$ & $40 \pm 14$ & $50 \pm 14$ \\
30 & $45 \pm 7$ & $50 \pm 0$ & $50 \pm 0$ & $60 \pm 0$ \\
LC10 value with 95\% confidence limits & $19.3(13.9-21.9)$ & $15.7(10.3-18.7)$ & $13.5(8.2-16.6)$ & $13.6(9.0-16.4)$ \\
LC50 value with 95\% confidence limits & $29.9(26.5-39.9)$ & $29.5(25.2-41.9)$ & $28.4(23.9-40.9)$ & $25.5(22.1-31.9)$ \\
LC90 value with 95\% confidence limits & $46.2(36.3-101.0)$ & $55.2(39.8-145.5)$ & $59.8(41.4-169.8)$ & $47.6(36.3-92.9)$ \\
\hline
\end{tabular}

Data were expressed as mean \pm SD $(n=3)$ 


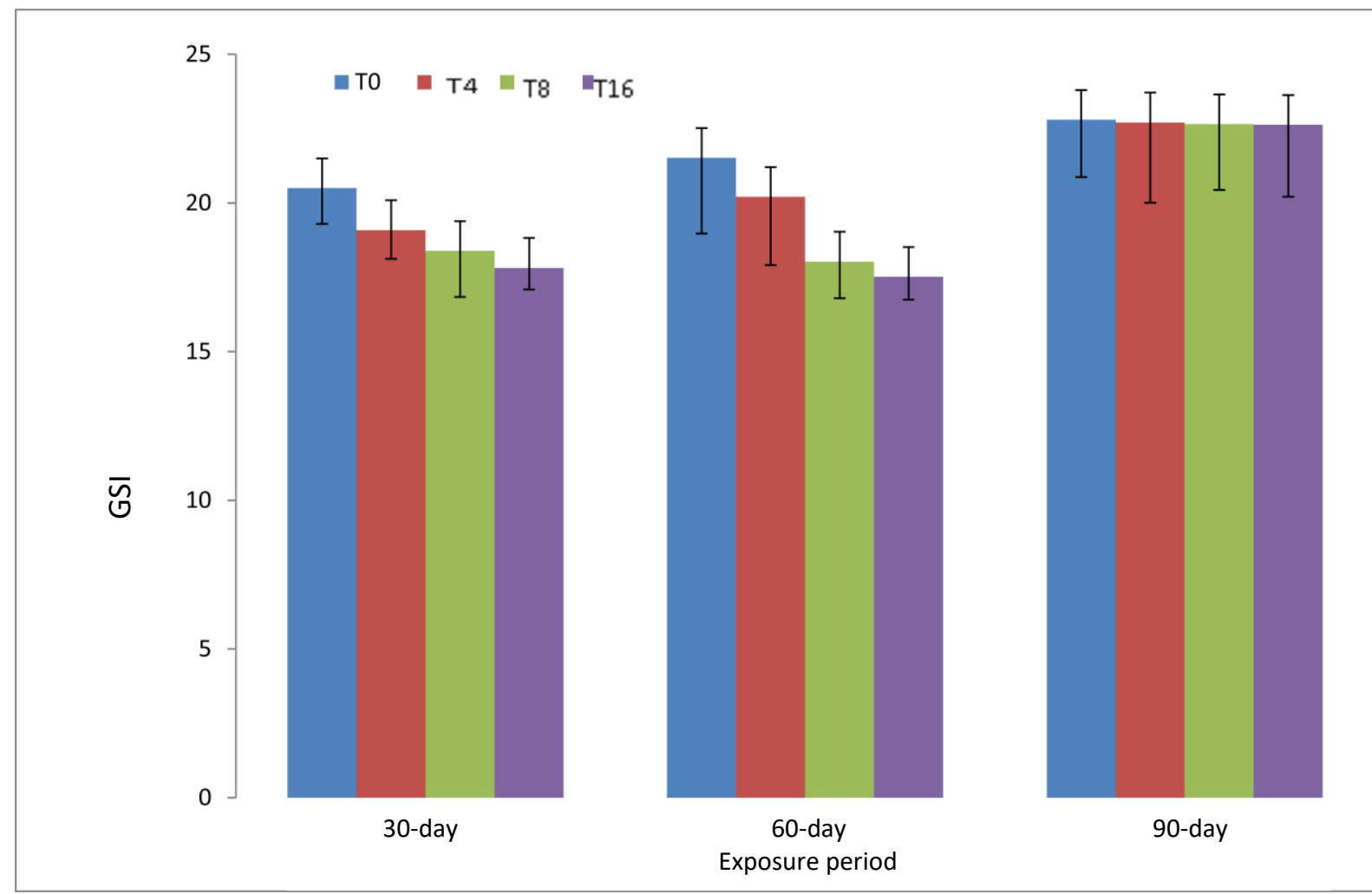

Figure 1. Gonadosomatic index of female Mystus cavasius exposed to cypermethrin for 90 days $(\mathrm{TO}=0 \mu \mathrm{g} / \mathrm{L} ; \mathrm{T} 4=4 \mu \mathrm{g} / \mathrm{L} ; \mathrm{T} 8=8 \mu \mathrm{g} / \mathrm{L}$ \& $\mathrm{T} 16=16 \mu \mathrm{g} / \mathrm{L})$.

\section{Effects of Cypermethrin on Ovary}

The ovaries extracted from the control fish did not show any histopathological alterations at day-30 associate with regular shape of nucleus (Figure $2 \mathrm{~A}$ ). After 30 days of pesticide exposure several abnormalities in female gonad were observed like WO (wrinkle oocyte), AF (atretic follicle), DGL (degenerated granulose layer) at pesticide concentration $4 \mu \mathrm{g} / \mathrm{L}$ (Figure 2B); IFS (inter follicular space), AD (adhesion) CC (cytoplasmic clumping) at $8 \mu \mathrm{g} / \mathrm{L}$ pesticide treated group (Figure 2C) and CT (cyst), DGL (degenerated granulose layer), CC (cytoplasmic clumping), DO (disrupted oocyte) at $16 \mu \mathrm{g} / \mathrm{L}$ pesticide exposure group (Figure 2D). Similarly, at day-60 and day-90 ovaries collected from control groups showed regular pattern of nucleus and granulose layer (Figure 3A \& 4A). The treated ovary showed DGL (degeneration of granulose layer), IFS (inter follicular space), AF (atretic follicle), CT (cyst), CC (cytolasmic clumping), AD (adhesion) were evident after 60 and 90 days of pesticide exposure (Figure 3B-3D and 4B-4D). Histopathological alterations of $M$. cavasius ovary exposed to different cypermenthrin concentration were found to be increased linearly with exposure time and concentrations (Table 2).

\section{Effects of Cypermethrin on Hemato-biochemical Parameters}

The blood glucose level is the amount of glucose (sugar) present in the blood of a human or animal which is the primary source of energy. Present study showed that blood glucose level increased significantly with increasing pesticide concentration and time of exposure. Blood glucose level was consecutively higher in the higher pesticide treated groups than the control group (Table 3). On the other hand, blood hemoglobin level showed opposite scenario i.e. the $\mathrm{Hb}$ level decreased significantly with increasing pesticide concentrations along with exposure time (Table 3). Whereas the numbers of RBCs and WBCs are significantly decreased and increased respectively with increasing pesticide exposure periods and concentrations (Table 3).

\section{Discussion}

\section{Effect of Cypermethrin on Mortality}

The 96-h LC50 of cypermethrin for Gangetic mystus was about $30 \mu \mathrm{g} / \mathrm{L}$ in the static bioassay. Ayoola et al. (2008) reported the 96-h lethal concentration (LC50) value of cypermethrin was $0.063 \mathrm{mg} / \mathrm{l}$ for Juvenile African Catfish (Clarias gariepinus) which is about two times higher than what we reported for Gangetic mystus. Marigoudar et al. (2009) found the 96-h LC50 value for Freshwater Teleost, Labeo rohita as $4.0 \mu \mathrm{g} / \mathrm{L}$ about seven times lower than our findings. Deka and Dutta (2012) revealed that the 96-h LC50 for Heteropneustes fossilis was about forty-five times lower than the present experiment as $0.67 \mu \mathrm{g} / \mathrm{L}$. Rabia Sarıkaya (2009) found 96-h the LC50 of cypermethrin for Nile 
tilapia was estimated as $5.99 \mu \mathrm{g} / \mathrm{L}$. Saha and Kaviraj (2007) estimated the 96-h LC50 value of aqueous cypermethrin ranged from $0.03 \mu \mathrm{g} / \mathrm{L}$ for the crustacean (Diaptomus Forbesi) to $9.0 \mu \mathrm{g} / \mathrm{L}$ for the tadpole larva (Bufo melanostictus). The higher LC50 value reported in the present study indicates that Gangetic mystus is less toxic to cypermethrin than some fish species which are tested in previous studies. The variation of sensitivity of fish to different chemicals depends on prevailing environmental conditions (Odukkathil and Vasudevan, 2013), physico-chemical properties of pesticides (AlEmran et al., 2021), size and age group of fish tested, and detoxification and absorption potential of fish (Oh et al., 2009).

\section{Effect of Cypermethrin on GSI}

The GSI value did not show the significant change ( $p>0.05$ ) from the first sampling (day-30) to the end of the experiment (day-90) among the control and treatments. Compared to control the GSI values was in decreasing trend with increasing pesticide concentration at day-30 and day-60 of pesticide exposure on the other hand it remains almost similar at day-90. This reduction in GSI value maybe due to delayed maturity, decrease in the percentage of different stages of oocytes as well as reduction in reproductive efficiency. An investigation was conducted to know the effects of organophosphate pesticide dimethoate (rogor) on the gonadosomatic index of the fish, Cyprinus carpio var. communis was. The GSI values was found to be increased in all control groups compared to the sub- lethal pesticide treated groups (0.85, 1.20 and $1.53 \mathrm{mg} / \mathrm{L}$ ) (Maqbool and Ahmed, 2013). However, the decreased in GSI was found directly proportional to the pesticide concentration and the period of the exposure (Mir et al., 2011).

\section{Effect of Cypermethrin on Ovary}

The current research found several dose and time dependent alterations in the ovarian histopathology of Gangetic mystus exposed to different concentrations of cypermethrin. The most common histopathological alterations in Gangetic mystus ovary when exposed to different concentrations of cypermethrin was degenerated granulose layer and oocyte wall. These two alterations induced by cypermethrin toxicity result in the loss of follicles or empty follicles, indicating that the genetic material within the follicles has been lost. The loss of genetic material in Gangetic mystus ovarian follicles may impede estrogen synthesis. The findings of this investigation are consistent with previous studies of Dutta and Maxwell (2003) and Maxwell and Dutta (2005) in Bluegill ovary exposed to diazinon; and Marutirao (2013) in Puntius ticto ovary exposed to dimethoate.

Inter follicular space can be caused by oocytes adhesion, as shown in our experiment. In the present study, fusion of oocytes accompanied with inter follicular space was noticed after 30 days and onwards of cypermethrin exposure to 8.0 and $16.0 \mu \mathrm{g} / \mathrm{L}$. Oocytes that adhered to one another are unable to progress to the next stages of maturation resulted the inhibition of
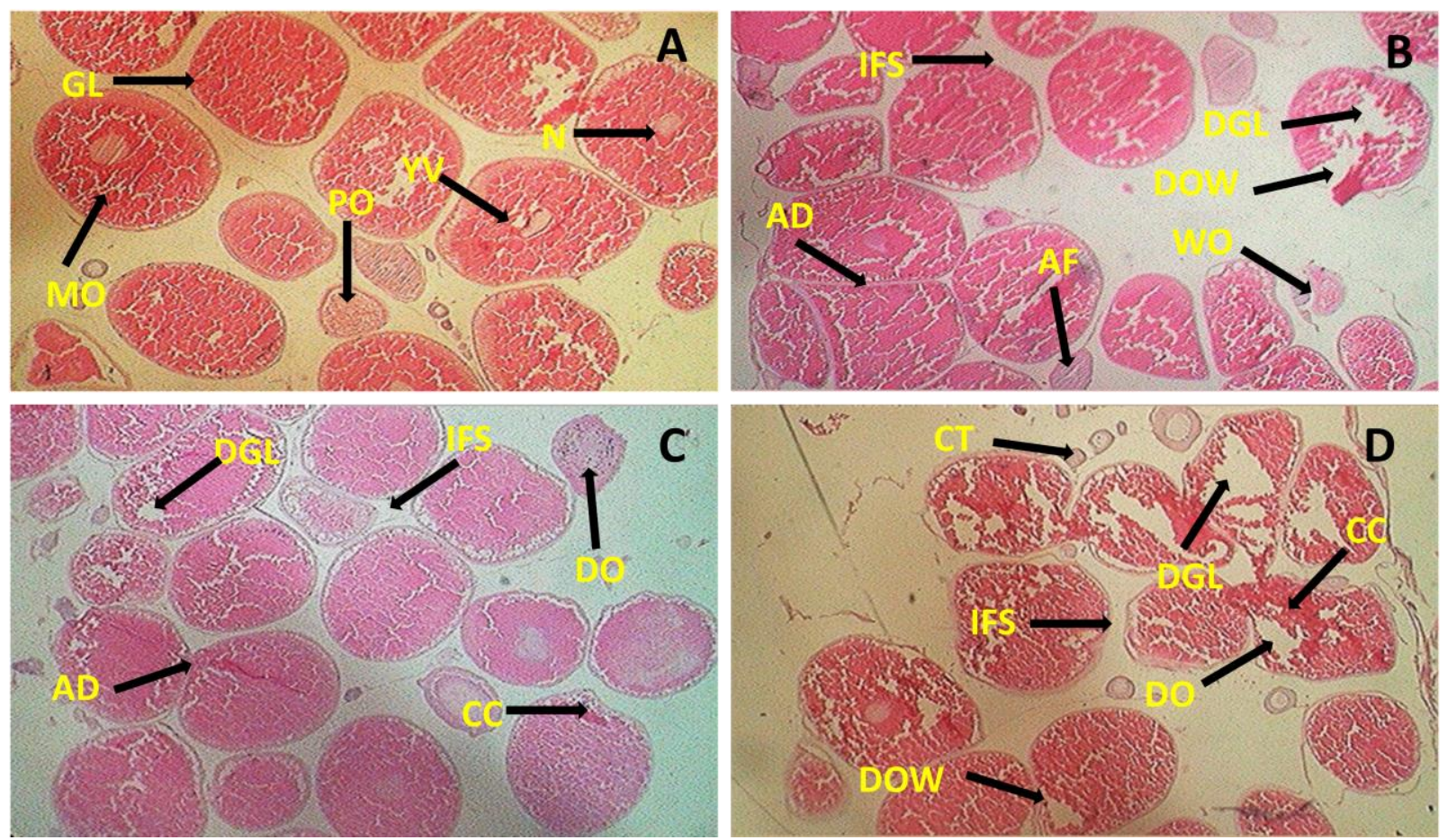

Figure 2. Histo-architectural changes in ovary exposed to cypermethrin at day-30; (A) Control $(0 \mu \mathrm{g} / \mathrm{L}),(\mathrm{B}) 4 \mu \mathrm{g} / \mathrm{L}$, (C) $8 \mu \mathrm{g} / \mathrm{L}$ and (D) $16 \mu \mathrm{g} / \mathrm{L}$. Arrow heads indicate mature oocyte (MO), pre-mature oocyte (PO), yolk vesicle (YV), wrinkle oocyte (WO), atretic follicle (AF), degenerated granulose layer (DGL), inter follicular space (IFS), adhesion (AD), cytoplasmic clumping (CC) cyst (CT), cytoplasmic clumping (CC), disrupted oocyte (DO). Magnification $4 \times$; scale bars $=100 \mu \mathrm{m}$. 

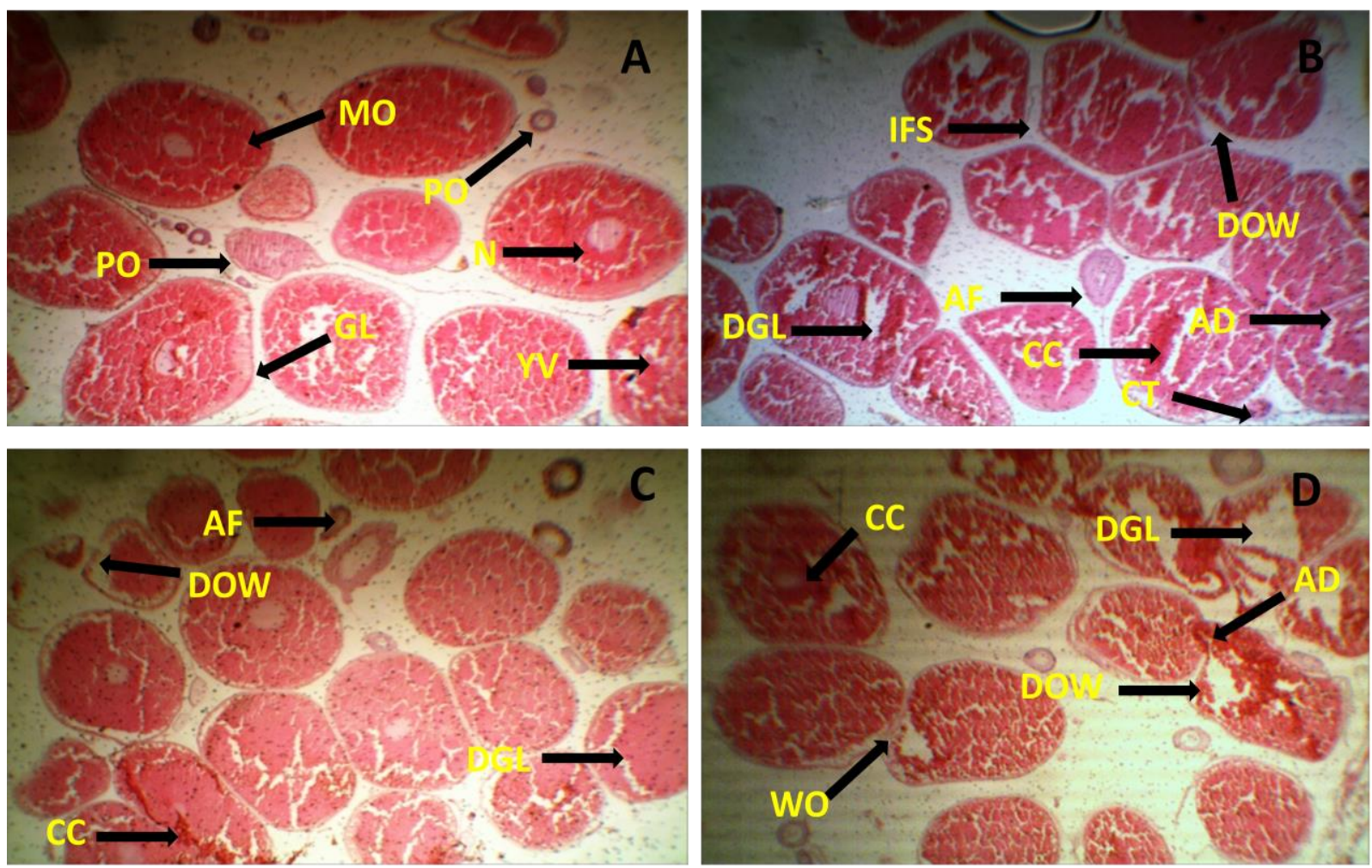

Figure 3. Histo-architectural changes in ovary exposed to cypermethrin at day-60; (A) Control ( $0 \mu \mathrm{g} / \mathrm{L})$, (B) $4 \mu \mathrm{g} / \mathrm{L}$, (C) $8 \mu \mathrm{g} / \mathrm{L}$ and (D) $16 \mu \mathrm{g} / \mathrm{L}$. Arrow heads indicate mature oocyte (MO), Nucleus (N), atretic follicle (AF), wrinkle oocyte (WO), inter follicular space (IFS), degenerated granulose layer (DGL), adhesion (AD), cytoplasmic clumping (CC) cyst (CT), cytoplasmic clumping (CC), disrupted oocyte (DO). Magnification 4x; scale bars $=100 \mu \mathrm{m}$
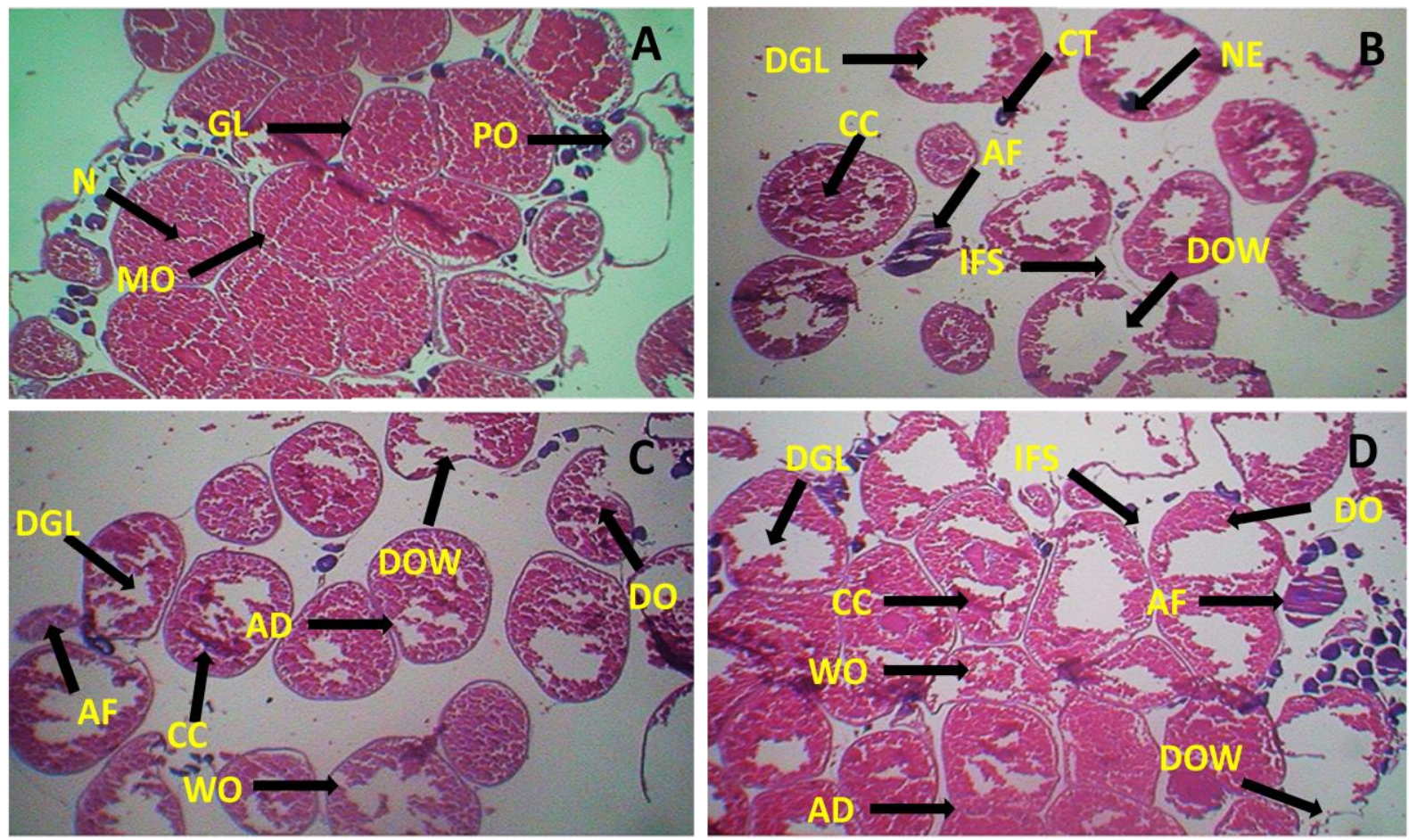

Figure 4. Histo-architectural changes in ovary exposed to cypermethrin at day-90; (A) Control (0 $\mu \mathrm{g} / \mathrm{L})$, (B) $4 \mu \mathrm{g} / \mathrm{L}$, (C) $8 \mu \mathrm{g} / \mathrm{L}$ and (D) $16 \mu \mathrm{g} / \mathrm{L}$. Arrow heads indicate mature oocyte (MO), granulose layer (GL), degenerated oocyte wall(DOW), atretic follicle (AF), wrinkle oocyte (WO), inter follicular space (IFS), degenerated granulose layer (DGL), adhesion (AD), cytoplasmic clumping (CC) cyst (CT), cytoplasmic clumping (CC), disrupted oocyte (DO). Magnification $4 \times$; scale bars $=100 \mu \mathrm{m}$. 
Table 2. Summary of histopathological alterations of $M$. cavasius ovary exposed to different concentrations of cypermethrin during the experimental period.

\begin{tabular}{|c|c|c|c|c|}
\hline \multirow[t]{2}{*}{ Alterations } & \multirow[t]{2}{*}{ Treatments $(\mu \mathrm{g} / \mathrm{L})$} & \multicolumn{3}{|c|}{ Sampling days } \\
\hline & & Day- 30 & Day- 60 & Day- 90 \\
\hline \multirow[t]{4}{*}{ Degenerated granulose layer (DGL) } & 0 & - & - & - \\
\hline & 4 & - & - & + \\
\hline & 8 & + & ++ & ++ \\
\hline & 16 & +++ & +++ & +++ \\
\hline \multirow[t]{4}{*}{ Atretic follicle (AF) } & 0 & - & - & - \\
\hline & 4 & - & - & - \\
\hline & 8 & - & ++ & ++ \\
\hline & 16 & ++ & +++ & +++ \\
\hline \multirow[t]{4}{*}{ Inter follicular space (IFS) } & 0 & - & - & - \\
\hline & 4 & - & + & + \\
\hline & 8 & ++ & ++ & ++ \\
\hline & 16 & +++ & +++ & +++ \\
\hline \multirow[t]{4}{*}{ Wrinkle oocyte (WO) } & 0 & - & - & - \\
\hline & 4 & - & - & - \\
\hline & 8 & + & + & +++ \\
\hline & 16 & ++ & ++ & +++ \\
\hline \multirow{4}{*}{ Adhesion (AD) } & 0 & - & - & - \\
\hline & 4 & - & + & + \\
\hline & 8 & + & + & + \\
\hline & 16 & ++ & ++ & ++ \\
\hline \multirow[t]{4}{*}{ Disrupted oocyte (DO) } & 0 & - & - & - \\
\hline & 4 & - & - & - \\
\hline & 8 & - & + & + \\
\hline & 16 & ++ & ++ & ++ \\
\hline \multirow[t]{4}{*}{ Cytoplasmic clumping (CC) } & 0 & - & - & - \\
\hline & 4 & - & - & - \\
\hline & 8 & + & ++ & ++ \\
\hline & 16 & ++ & ++ & ++ \\
\hline \multirow[t]{4}{*}{ Cyst (CT) } & 0 & - & - & - \\
\hline & 4 & - & + & + \\
\hline & 8 & ++ & + & ++ \\
\hline & 16 & +++ & +++ & +++ \\
\hline \multirow[t]{4}{*}{ Degenerated oocyte wall (DOW) } & 0 & - & - & - \\
\hline & 4 & - & + & ++ \\
\hline & 8 & ++ & ++ & +++ \\
\hline & 16 & +++ & +++ & +++ \\
\hline \multirow[t]{4}{*}{ Necrosis (NE) } & 0 & - & - & - \\
\hline & 4 & - & + & + \\
\hline & 8 & + & + & + \\
\hline & 16 & ++ & ++ & ++ \\
\hline
\end{tabular}

$(-)$ indicates absent, (+) low frequent, (++) moderately frequent, (+++) highly frequent

Table 3. Summary of hemato-biochemical parameters of $M$. cavasius after exposed to different concentrations of cypermethrin concentrations during the experimental period

\begin{tabular}{|c|c|c|c|c|}
\hline \multirow[t]{2}{*}{ Parameters } & \multirow[t]{2}{*}{ Treatments $(\mu \mathrm{g} / \mathrm{L})$} & \multicolumn{3}{|c|}{ Sampling Days } \\
\hline & & Day-30 & Day-60 & Day-90 \\
\hline \multirow{4}{*}{ Blood glucose (mg/dL) } & 0 & $5.9 \pm 0.01^{a}$ & $5.6 \pm 0.03^{a}$ & $5.7 \pm 0.01^{\mathrm{a}}$ \\
\hline & 4 & $6.5 \pm 0.07^{a}$ & $5.8 \pm 0.05^{\mathrm{a}}$ & $7.2 \pm 0.03^{a}$ \\
\hline & 8 & $8.1 \pm 0.11^{b}$ & $6.8 \pm 0.19^{b}$ & $7.8 \pm 0.05^{a}$ \\
\hline & 16 & $10.4 \pm 0.18^{c}$ & $9.9 \pm 0.28^{c}$ & $10.1 \pm 0.17 c$ \\
\hline \multirow[t]{4}{*}{$\mathrm{Hb}(\%)$} & 0 & $9.8 \pm 0.01^{c}$ & $9.6 \pm 0.01^{c}$ & $9.9 \pm 0.01^{c}$ \\
\hline & 4 & $7.7 \pm 0.04^{b}$ & $7.3 \pm 0.05^{b}$ & $7.8 \pm 0.07^{b}$ \\
\hline & 8 & $6.1 \pm 0.04^{b}$ & $6.5 \pm 0.04^{b}$ & $6.7 \pm 0.04^{b}$ \\
\hline & 16 & $4.6 \pm 0.11^{a}$ & $4.3 \pm 0.17^{a}$ & $4.8 \pm 0.09^{a}$ \\
\hline \multirow[t]{4}{*}{$\mathrm{RBC}\left(\times 10^{6} / \mathrm{mm}^{3}\right)$} & 0 & $3.4 \pm 0.03^{c}$ & $3.2 \pm 0.03^{c}$ & $1.8 \pm 0.05^{c}$ \\
\hline & 4 & $1.8 \pm 0.05^{b}$ & $1.9 \pm 0.04^{b}$ & $1.5 \pm 0.03^{b}$ \\
\hline & 8 & $0.4 \pm 0.04^{a}$ & $1.7 \pm 0.05^{b}$ & $1.4 \pm 0.04^{b}$ \\
\hline & 16 & $0.5 \pm 0.13^{a}$ & $1.3 \pm 0.17^{a}$ & $1.1 \pm 0.04^{a}$ \\
\hline \multirow[t]{4}{*}{ WBC $\left(\times 10^{3} / \mathrm{mm}^{3}\right)$} & 0 & $38.3 \pm 0.03^{a}$ & $35.3 \pm 0.03^{a}$ & $26.0 \pm 0.05^{a}$ \\
\hline & 4 & $60.8 \pm 0.04^{c}$ & $47.0 \pm 0.07^{c}$ & $34.3 \pm 0.07^{b}$ \\
\hline & 8 & $44.6 \pm 0.06^{b}$ & $43.3 \pm 0.09^{b}$ & $32.5 \pm 0.11^{b}$ \\
\hline & 16 & $48.0 \pm 0.07^{b}$ & $50.3 \pm 0.11^{c}$ & $53.8 \pm 0.01^{c}$ \\
\hline
\end{tabular}

Values with different alphabetical superscripts in a row differ significantly $(\mathrm{p}<0.05)$ among different treatments. All values were expressed as mean \pm SD. 
steroids production in the ovary. The results of our study confirm with those of earlier studies in Bluegill ovary after $72 \mathrm{~h}$ of diazinon exposure to $60 \mathrm{mg} / \mathrm{L}$ (Maxwell and Dutta, 2005; Dutta and Maxwell, 2003).

Cytoplasmic degeneration like cytoplasmic clumping (CC) was observed among the three sampling days exposure to both 8.0 and $16.0 \mu \mathrm{g} / \mathrm{L}$ of cypermethrin. Earlier studies demonstrated a substantial link between the damaged ovarian structures and levels of estrogen production in fish exposed to different pesticides (Manjunatha and Philip, 2016; Maxwell and Dutta, 2005). Deka and Mahanta (2012) found cytoplasmic degenerations in Stinging Catfish (Heteropneustes fossilis) ovary after exposed to $200 \mathrm{mg} / \mathrm{L}$ malathion for 10 days. The cytoplasmic alterations were also observed in previous studies in Bluegill (Lepomis macrochirus) ovary exposed to diazinon (Maxwell and Dutta, 2005) and in Puntius ticto ovary exposed to dimethoate (Marutirao, 2013).

Follicular atresia in Gangetic mystus ovary was detected after 60 and 90 days of cypermethrin exposure to $8.0 \mu \mathrm{g} / \mathrm{L}$, as well as after all three sampling days of cypermethrin exposure to $16.0 \mu \mathrm{g} / \mathrm{L}$. The presence of follicular atresia in cypermethrin-exposed ovaries of Gangetic mystus at oocyte stages could reflect an interruption in the normal processes of final maturation of oocytes as well as disturbances of ovulation and oviposition, finally reduction of fertility. The atretic follicles were observed by Manjunatha and Philip (2016) in Zebrafish (Danio rerio) ovaries after an acute exposure (96 h) to $200 \mathrm{mg} / \mathrm{L}$ of chlorpyrifos; by Dutta and Maxwell (2003) in Bluegill ovary exposed to diazinon and by Narayanaswamy and Mohan (2014) in Glossogobius giuris ovary exposed to malathion. The follicular atresia was also noticed in Puntius ticto ovary after a chronic exposure to dimethoate (Marutirao, 2013) and in Channa punctatus ovary after a sub-chronic exposure to monocrotophos (Maqbool and Ahmed, 2013).

Necrosis was evident in Gangetic mystus ovary after exposure to 4.0, 8.0 and $16.0 \mu \mathrm{g} / \mathrm{L}$ at Day-30, Day60 and Day-90. This indicated the lack or absence of genetic material after a longterm exposure, which may reduce the hormone production. Maqbool and Ahmed (2013) observed similar alterations in Channa punctatus ovary after 45 days of $2,000 \mathrm{mg} / \mathrm{L}$ monocrotophos exposure. Necrosis or loss of genetic materials was also observed in Stinging Catfish ovary after an acute exposure to malathion (Dutta et al., 1994) and in Bluegill ovary exposed to diazinon (Maxwell and Dutta, 2005).

\section{Alteration of Hemato-biochemical Parameters Exposed to Cypermethrin}

Blood glucose levels are general stress indicators in fish (Pacheco and Santos 2001). In the present study, increased glucose levels recorded in the fish exposed to cypermethrin might be due to the mobilization of glycogen into glucose to meet the increased demand for energy under stressed condition due to pesticide exposure. Glucocorticoids and catecholamine hormones are known to produce hyperglycemia in animals and stress stimuli elicit rapid secretion of these hormones from adrenal tissues of the fish (Pickering 1981). Fresh water catfish $H$. fossilis exposed to different pesticide concentrations such as rogor and aldrin reported hypoglycemia (Borah et al., 1995). Such elevation may be due to the increased reaction of stressed fish to gluconeogenesis to meet their additional energy requirements (Winkaler et al., 2007). Chowdhury et al. (2000) reported that $H$. fossilis subjected to testosterone sub-lethal concentrations resulted to change of blood glucose level. This is likely owing to the fast use of blood glucose during hyper excitability, shocks and tremors, characteristic behavior of fish toxicity to pesticides (Singh et al., 1982).

In the current research, $\mathrm{Hb}$ content in the blood of the fish exposed to the different concentrations of cypermethrin decreased significantly. The observed decrease in hemoglobin levels might be because of failing of hematopoietic system under stressed condition in Gangetic mystus. A similar reduced value of $\mathrm{Hb}$ was also reported in common carp exposed to sumithion (Salam et al., 2015) and malathion (Sharmin et al., 2015). Similar to $\mathrm{Hb}$, the number of RBCs was found to be decreased in fishes subjected to different concentrations of cypermethrin, also might be because of failing of hematopoietic system. Similar to the present results, a decrease in the number of RBC was reported in rainbow trout exposed to diazinon (Banaee et al., 2011) and in Clarias gariepinus exposed to lead nitrates (Adeyemo et al., 2008). Inhibition of erythropoiesis and increase in the rate of erythrocyte destruction in hematopoietic organs is the cause of decrease in RBC count (Joshi et al., 2002). In the present study, the significant decrease of RBC content might have resulted from the oxygen deficiency in the body or from the lowering content of the water due to the presence of cypermethrin.

Remarkably, there was a significant increase in WBC count in the blood of fishes exposed to different concentrations of cypermethrin, which can be correlated with an increase in antibody production that helps in survival of the fish in adverse environmental condition. The immediate stimulation of immunological defense may result in leucocytosis in fish due to the presence of foreign particles or stressed conditions (Marti et al., 1996). The rise in the number of WBCs can be linked with rise in the manufacturing of antibodies, which helps in the survival and regeneration of stressors exposed fish (Joshi et al., 2002)

\section{Ethical Statement}

The experimental protocol was approved by the Ethics Committee of Bangladesh Agricultural University, Mymensingh, Bangladesh. 


\section{Funding Information}

Not applicable.

\section{Author Contribution}

Md Helal Uddin: Conceptualization, Methodology, Writing -review and editing; Md Haider Ali: Experimentation, Methodology and Data Curation; Kizar Ahmed Sumon: Resources and Analysis; Md Shahjahan: Investigation and Visualization; Harunur Rashid: Supervision, review and editing.

\section{Conflict of Interest}

The authors declare no competing interests.

\section{Acknowledgements}

The authors are thankful to Mr. Shohid laboratory in charge for this support to conduct the research and all laboratory staffs, is thankfully acknowledged.

\section{References}

Adeyemo, O. K., Ajani, F., Adedeji, O. B., \& Ajiboye, O. O. (2008). Acute Toxicity and Blood Profile of Adult Clarias gariepinus Exposed to Lead Nitrate. The Internet Journal of Hematology, 4(2).

Ali, M. H., Sumon, K. A., Sultana, M., \& Rashid, H. (2018). Toxicity of cypermethrin on the embryo and larvae of gangetic mystus, Mystus cavasius. Environmental Science \& Pollution Research, 25, 3193-3199. https://doi.org/10.1007/s11356-017-9399-1.

Ayoola, S. O., \& Ajani, E. K. (2008). Histopathological Effects of Cypermethrin on Juvenile African Catfish (Clarias gariepinus). World Journal of Biological Research, 19945108. https://ir.unilag.edu.ng/handle/123456789/6338.

Banaee, M., Mirvagefei, A. R., Rafei, G. R., \& Majazi, A. B. (2008). Effect of sub-lethal diazinon concentrations on blood plasma biochemistry. International Journal of Environmental Research, 2(2), 189-198. https://www.sid.ir/en/journal/ViewPaper.aspx?id=103035.

Banaee, M., Sureda, A., Mirvaghefi, A. R., \& Ahmadi, K. (2011). Effects of diazinon on biochemical parameters of blood in rainbow trout (Oncorhynchus mykiss), Pesticide Biochemistry \& Physiology, 99, 1-6. https://doi.org/10.1016/j.pestbp.2010.09.001.

Borah, S., \& Yadav, R. N. S. (1995). Static bioassay and toxicity of two pesticides. rogor and endosulfan to air breathing fish Heteropneustes fossilis with special reference to behaviour, Pollution Research, 14, 435-438.

Cazenave, J., Wunderlin, D. A., Hued, A. C., \& de los AngelesBistoni, M. (2005). Haematological parameters in a neotropical fish, Corydoras paleatus (Jenyns, 1842) (Pisces, Callichthyidae), captured from pristine and polluted water. Hydrobiologia, 537, 25-33. https://doi.org/10.1007/s10750-004-1638-z.

Chowdhury, I., \& Joy, K. P. (2000). Effects of administration of testosterone on some biochemical correlates in seminal vesicle of Heteropneustes fossilis (Bloch) during preparatory phase: a study correlating changes in plasma testosterone and testis activity, Indian Journal of
Experimental Biology, 38, 713-719.

http://nopr.niscair.res.in/handle/123456789/24029.

Correia, J. E., Christofoletti, C. A., Marcato, A. C. C., Marinho, J. F. U., \& Fontanetti, C. (2017). Histopathological analysis of tilapia gills (Oreochromis niloticus Linnaeus, 1758) exposed to sugarcane vinasse. Ecotoxicology \& Environmental Safety, 135, 319-326. https://doi.org/10.1016/j.ecoenv.2016.10.004.

Crane, M., \& Maltby, L. (1991). The lethal and sublethal responses of gammarus pulex to stress: sensitivity and sources of variation in an in situ bioassay. Environmental Toxicology \& Chemistry, 10, 1331-1339. https://doi.org/10.1002/etc.5620101012.

Dasgupta, S., Meisner, C., \& Huq, M. (2007). A pinch or a pint. Evidence of pesticide overuse in Bangladesh. Journal of Agricultural Economy, 58, 91-114. https://doi.org/10.1111/j.1477-9552.2007.00083.x.

De Silva, P. M. C. S., \& Samayawardhena, L. A. (2005). Effects of chlorpyrifos on reproductive performances of guppy (Poecilia reticulata). Chemosphere, 58, 1293-1299. https://doi.org/10.1016/j.chemosphere.2004.10.030.

Deka, C., \& Dutta, K. (2012). Effects of cypermethrin on some haematological Parameters in Heteropneustes fossilis (bloch). The Bioscan, 7(2), 221-223.

Deka, S., \& Mahanta, R. (2012). A study on the effect of organophosphorus pesticide malathion on hepato-renal and reproductive organs of Heteropneustes fossilis (Bloch). Science Probe, 1, 1-13.

Dutta, H. M., Nath, A., Adhikari, S., Roy, P. K., Singh, N. K., \& Munshi, J. S. D. (1994). Sublethal malathion induced changes in the ovary of an air-breathing fish, Heteropneustes fossilis: A histological study. Hydrobiologia, 294, 215-218. https://doi.org/10.1007/BF00021294.

Dutta, H. M., \& Maxwell, L. B. (2003). Histological examination of sublethal effects of diazinon on ovary of bluegill, Lepomis macrochirus. Environmental Pollution. 121, 95102. https://doi.org/10.1016/S0269-7491(02)00201-4.

Elahee, K. B., \& Bhagwant, S. (2007). Hematological and gill histopathological parameters of three tropical fish species from a polluted lagoon on the west coast of Mauritius. Ecotoxicology \& Environmental Safety, 68 361-371. https://doi.org/10.1016/j.ecoenv.2006.06.003.

Emran, M. A., Hasan, N. A., Khan, M. P., Islam, S. M. M., Bashar, A., Zulfahmi, I., Shahjahan, M. \& Sumon, K. A. (2021). Alterations in hematological parameters and the structure of peripheral erythrocytes in Nile tilapia (Oreochromis niloticus) exposed to profenofos. Environmental Science and Pollution Research. https://doi.org/10.1007/s11356-021-17972-8.

Gupta, A., Rai, D. K., Pandey, R. S., \& Sharma, B. (2009). Analysis of some heavy metals in the riverine water sediments and fish from river Ganges at Allahabad. Environmental Monitoring \& Assessment, 157, 449-458. https://doi.org/10.1007/s10661-008-0547-4.

Joshi, P. K., Bose, M., \& Harish, D. (2002). Haematological changes in the blood of Clarias batrachus exposed to mercuric chloride. Journal of Ecotoxicology \&. Environmental Monitoring, 12, 119-122.

Lohner, T. W., Reash, R. J., \& Williams, M. (2001). Assessment of Tolerant Sunfish Populations (Lepomis sp.) Inhabiting Selenium-Laden Coal Ash Effluents: 2. Tissue Biochemistry Evaluation. Ecotoxicology and Environmental Safety, 50, 203-216. https://doi.org/10.1006/eesa.2001.2098. 
Manjunatha, B., \& Philip, G. H. (2016). Reproductive toxicity of chlorpyrifos tested in zebrafish (Danio rerio): Histological and hormonal end points. Toxicology and Industrial Health, 1-9. https://doi.org/10.1177/0748233715589445.

Maqbool, A., \& Ahmed, I. (2013). Effects of pesticide monocrotophos (organophosphate), on the gonadal development of female freshwater murrel, Channa punctatus (Bloch). International Journal of Recent Scientific Research, 4, 1454-1458.

Marigoudar, S. R., Ahmed, R. N., \& David, M. (2009). Impact of Cypermethrin on Behavioural Responses in the Freshwater Teleost, Labeo rohita (Hamilton). World Journal of Zoology, 4 (1), 19-23.

Marti, H. H., Wenger, R. H., \& Rivas, L. A. (1996). Erythropoietin gene expression in human, monkey and murine brain, European Journal of Neuroscience, 8 (4), 666-676. https://doi.org/10.1111/j.1460-9568.1996.tb01252.x.

Marutirao, G.R. (2013). Histopathological changes in the ovary of freshwater fish Puntius ticto (Ham) under dimethoate toxicity. Bioscan, 8, 989-992.

Maxwell, L. B., \& Dutta, H. M. (2005). Diazinon-induced endocrine disruption in bluegill sunfish, Lepomis macrochirus. Ecotoxicology \& Environmental Safety, 60 21-27. https://doi.org/10.1016/j.ecoenv.2003.12.015.

Mir, F. A., Shah, G. M., Jan, U., Mir, J. I., \& Dubey, V. K. (2011). Studies on influences of sublethal concentration of organophosphate pesticide-dimethoate (rogor), on gonadosomatic index (GSI) of female common carp, cyprinus carpio communis. Ecophysiology ana Occupational Health, 11, 117-121. https://doi.org/10.18311/JEOH\%2F2011\%2F2256.

Miren, P., Cajaraville, M. J., Bebianno, J. B., Cinta, P., Carmen, S., \& Aldo, V. (2000). The use of biomarkers to assess the impact of pollution in coastal environments of the Iberian peninsula: a practical approach. Science of the Total Environment, 247, 295-311. https://doi.org/10.1016/s0048-9697 (99)00499-4.

Narayanaswamy, S.Y., \& Mohan, M.R. (2014). Histopathological studies on hypophysis and ovary of freshwater fish Glossogobius giuris (Hamilton). World Journal of Pharmacy and Pharmaceutical Sciences, 3 , 841-862.

Narra, M. R., Begum, G., Rajender, K., \& Rao, J. V. (2011). Sublethal effect of chlorpyrifos on protein metabolism of the food fish Clarias batrachus and monitoring of recovery. Toxicological \& Environmental Chemistry, 93, 16501658. https://doi.org/10.1080/02772248.2011.593520.

Odukkathil, G., \& Vasudevan, N. (2013). Toxicity and bioremediation of pesticides in agricultural soil. Reviews in Environmental Science and Biotechnology, 12, 421444.

Oh, H. S., Lee, S. K., Kim, Y. H., \& Roh, J. K. (2009). Mechanism of selective toxicity of diazinon to killifish (Oryzias latipes) and Loach (Misgurnus anguillicaudatus). In: Barron M, Mayes M (eds) Aquatic toxicology and risk assessment. ASTM International, West Conshohocken, PA, 343-353. 10.1520/STP23584S.

Okomoda, V. T., Ataguba, G. A., \& Ayuba, V. O. (2013). Hematological response of Clarias gariepinus fingerling sexposed to acute concentrations of Sunsate ${ }^{\circledR}$. Journal of Stress Physiology \& Biochemistry, 9 (2), 271-278.

Pacheco, M., \& Santos, M. A. (2001). Biotransformation, endocrine, and genetic responses of Anguilla Anguilla L. to petroleum distillate products and environmentally contaminated waters. Ecotoxicology and Environmental Safety, 49, 64-75.

Pickering, A. D. (1981). Stress and compensation in teleostean fishes: response to social and physical factors. In Pickering AD (ed) Stress and fish. Academic Press, New York, 295-322.

Rani, G. I., \& Kumaraguru, A. K. (2014). Behavioural responses and acute toxicity of Clarias batrachus to synthetic pyrethroid insecticide, cyhalothrin. Journal of Environmental Applied Bioresource, 2(1), 19-24. http://jeab.scienceresearchlibrary.com/admin/uploads/ cMDq2J.pdf.

Ruane, N. M., Nolan, D. T., Rotllant, J., Costelloe, J., \& Bonga, S. E. W. (2000). Experimental exposure of rainbow trout Oncorhynchus mykiss (Walbaum) to the infective stages of the sea louse Lepeophtheirus salmonis (Kroyer) influences the physiological response to an acute stressor. Fish Shellfish Immunology, 10 (5), 451-463. https://doi.org/10.1006/fsim.1999.0260.

Rubach, M. N., Baird, D. J., Boerwinkel, M., Maund, S. J., Roessink, I., \& Van den Brink, P. J. ( 2012). Species traits as predictors for intrinsic sensitivity of aquatic invertebrates to the insecticide chlorpyrifos. Ecotoxicology, 21, 2088-2101. https://doi.org/10.1007/s10646-012-0962-8.

Rubach, M. N., Crum, S. J. H., \& Van den Brink, P.J. (2011). Variability in the dynamics of mortality and immobility responses of freshwater arthropods exposed to chlorpyrifos. Archives of Environmental Contamination and Toxicology, 60:708-721. https://doi.org/10.1007/s00244-010-9582-6.

Sachsen, D. N., \& Sultana, S. (1999). A study of the effect of two organophosphorus pesticides namely nuvan $(0.27$ ppm) and dimecron (0.55 ppm) on Channa orientalis for a period of 30 and 45 days. Indian Journal of Fisheries, 8, 111-134.

Saeedi, F. M., Roodsari, H. V., Zamini, A., Mirrasooli, E., \& Kazemi, R. (2012). The effects of diazinon on behavior and some hematological parameters of fry rainbow trout (Oncorhynchus mykiss). World Journal of Fish and Marine Sciences, 4(4), 369-375.

Saha, S., \& Kaviraj, A. (2008). Acute Toxicity of Synthetic Pyrethroid Cypermethrin to Some Freshwater Organisms. Bulletin of Environmental Contamination and Toxicology, 80, 49-52. https://doi.org/10.1007/s00128007-9314-4.

Salam, M. A., Shahjahan, M., Sharmin, S., Haque, F., \& Rahman, M. K. (2015). Effects of sub-lethal doses of an organophosphorous insecticide sumithion on some hematological parameters in common carp, Cyprinus carpio. Pakistan Journal of Zoology, 47(5), 1487-1491.

Sarıkaya, R. (2009). Investigation of Acute Toxicity of AlphaCypermethrin on Adult Nile Tilapia (Oreochromis niloticus L.). Turkish Journal of Fisheries and Aquatic Sciences, 9, 85-89.

Satyavardhan, K. (2013). A comparative toxicity evaluation and behavioral observations of fresh water fishes to Fenvalerate. Middle-East Journal of Scientific Research 13(2):133-136. DOI: 10.5829/idosi.mejsr.2013.13.2.813.

Shahjahan, M., Kabir, M. F., Sumon, K. A., Bhowmik, L. R., \& Rashid, H. (2017). Toxicity of organophosphorus pesticide sumithion on larval stages of stinging catfish Heteropneustes fossilis. Chinese Journal of Oceanology and Limnology, 35, 109-114. 
Sharmin, S., Shahjahan, M., Hossain, M. A., Haque, M. A., \& Rashid, H. (2015). Histopathological changes in liver and kidney of common carp exposed to sub-lethal doses of malathion. Pakistan Journal of Zoology, 47(5), 14951498.

Singh, H., \& Singh, T. P. (1982). Effect of some pesticides on hypothalamo-hypophysealovarian axis in the freshwater catfish, Heteropneustes fossilis (Bloch), Environmental Pollution, 27, 283-288. https://doi.org/10.1016/01431471(82)90156-8.

Sumon, K. A., Rico, A., Ter Horst, M. M. S., Van den Brink, P. J., Haque, M. M., \& Rashid, H. (2016). Risk assessment of the pesticides used in rice-prawn concurrent system in Bangladesh. Science of the Total Environment, 568, 498506. https://doi.org/10.1016/j.scitotenv.2016.06.014.

Sumon, K. A., Saha, S., Van den Brink, P. J., Peeters, E. T. H. M., Bosma, R. H., \& Rashid, H. (2017). Acute toxicity of chlorpyrifos to embryo and larvae of banded gourami Trichogaster fasciata. Journal of Environmental Science and Health, Part B, 52, 92-98.

https://doi.org/10.1080/03601234.2016.1239979.

Talwar, P. K., \& Jhingran, A. G. (1991). Inland fishes of India and adjacent countries. Oxford IBH Publishing Co Pvt Ltd, New Delhi-Calcutta2, pp543 e-1158.
Thrall, M. A. (2004). Veterinary hematology and clinical chemistry. Williams and Wilkins, Philadelphia, pp 277289.

Ullah, R., Zuberi, A., Tariq, M., \& Ullah, S. (2014). Toxicity to hematology and morphology of liver, brain and gills during acute exposure of mahseer (Tor putitora) to cypermethrin. International Journal of Agriculture and Biology, 17(1), 199-204.

Van den Brink, P. J. (2013). Assessing aquatic population and community level risks of pesticides. Environmental Toxicology and Chemistry, 32, 972-973. https://doi.org/10.1002/etc.2210.

Wilson, R. W., \& Taylor, E. W. (1993). The physiological responses of freshwater rainbow trout, Onchorynchus mykiss, during acute exposure. Journal of Comparative Physiology B, 163, 38-47. https://doi.org/10.1007/BF00309663.

Winkaler, E. U., Santosh, T. R. M., Machdo-Neto, J. G., \& Martinez, C. B. R. (2007). Acute lethal and sub-lethal effects of neem leaf extracts on neotropical freshwater fish, Prochilodus lineatus, Comparative Biochemistry and Physiology Part C, 145, 236-244. https://doi.org/10.1016/j.cbpc.2006.12.009.

Yadav, B. N. (1997). Fish and fisheries. Daya Publishing House, Delhi, India 366. 